\title{
Effect of Thermochemical Modification of Activated Carbon Materials on Specific Capacity of Electrochemical Capacitors
}

\author{
B. K. Ostafiychuk ${ }^{1}$, I. M. Budzulyak ${ }^{1}$, A. I. Kachmar ${ }^{1}$, O. H. Tadeush ${ }^{2}$, \\ B. I. Rachiy ${ }^{1}$, R. P. Lisovsky ${ }^{1}$, R. I. Merena ${ }^{3}$, and M. V. Berkeshchuk ${ }^{4}$ \\ ${ }^{1}$ SHEE 'Vasyl Stefanyk Precarpathian National University', \\ 57, Shevchenko Str., \\ UA-76018 Ivano-Frankivsk, Ukraine \\ ${ }^{2}$ South Ukrainian National Pedagogical University named after K. D. Ushinsky, \\ 26, Staroportofrankivs'ka Str., \\ UA-65020 Odesa, Ukraine \\ ${ }^{3}$ Ivano-Frankivsk National Medical University, \\ 2, Halytska Str., \\ UA-76018 Ivano-Frankivsk, Ukraine \\ ${ }^{4}$ Ivan Ohienko Kamyanets-Podilskyi National University, \\ 61, Ohienko Str., \\ UA-32300 Kamyanets-Podilskyi, Ukraine
}

The article presents the results of electrochemical and morphological investigations of nanoporous carbon as an electrode material for electrochemical capacitors. Nanoporous carbon material is obtained from raw vegetable materials via carbonization and subsequent activation by sodium hydroxide. The optimum conditions of activation of nanoporous carbon are set, at which the maximum specific capacity of electrochemical capacitors formed on its base is $140 \mathrm{~F} / \mathrm{g}$. As shown, the state and morphology of the developed surface greatly affect the value of specific capacity.

У роботі представлено результати електрохемічних і морфологічних досліджень нанопористого вуглецю як електродного матеріялу для електрохемічних конденсаторів (ЕК). Нанопористий вуглецевий матеріял (HBM) було одержано із сировини рослинного походження шляхом її карбонізації та наступної активації натрій гідроксидом. Встановлено оптимальні умови активації НВМ, за яких досягнуто максимальну питому ємність (140 Ф/г) EК, сформованих на його основі. Показано, що на величину питомої ємности істотно впливає стан і морфологія розвинутої поверхні.

В работе представлены результаты электрохимических и морфологических исследований нанопористого углерода как электродного материала для электрохимических конденсаторов (ЭК). Нанопористый углеродный 
материал (НУМ) получен из сырья растительного происхождения путём его карбонизации и последующей активации натрий гидроксидом. Установлены оптимальные условия активации НУМ, при которых достигнута максимальная удельная ёмкость (140 Ф/г) ЭК, сформированных на его основе. Показано, что на величину удельной ёмкости существенно влияет состояние и морфология развитой поверхности.

Keywords: nanoporous carbon, aqueous electrolyte, capacity, voltage drop.

Ключові слова: нанопористий вуглець, водний електроліт, ємність, спад напруги.

Ключевые слова: нанопористый углерод, водный электролит, ёмкость, падение напряжения.

(Received 16 April, 2018)

\section{INTRODUCTION}

The problem of porous structure forming in carbon materials as the basis of supercapacitors electrodes is relevant both in scientific and applied terms, since carbon is not only the basis of classical supercapacitors operating on the charge/discharge of the double electric layer (DEL), but also is practically an integral part of the devices of hybrid and pseudo-capacitive accumulation of charge $[1,2]$. The reason for this one is the ability to create unique structures of carbon atoms such as nanotubes, fullerene, and graphene.

The fractal structure of the pores formed in nanoporous carbon (NC) in different ways determines the possibilities of carbon application in charge accumulation devices [1,3]. In particular, the pore-sizes' distribution and specific surface area are the most important characteristics, without which it is impossible to select one or another electrolyte, to establish the optimal ratio between the internal resistance and specific capacity of the device, to provide a constant Coulomb efficiency for large $\left(10^{6}\right)$ number of charge/discharge cycles.

\section{OBJECTS AND METHODS}

NC was used as an active material obtained from plant raw materials through carbonization with the following chemical activation. The feedstock was dry apricot seeds milled to a fraction size of $0.25-1 \mathrm{~mm}$. Their carbonization was carried out in the closed furnace at $900-920^{\circ} \mathrm{C}$ with a heating rate of $10^{\circ} \mathrm{C} \cdot \mathrm{min}^{-1}$. The resulting carbonized material was milled to a fraction size of $200-250 \mu \mathrm{m}$ and mixed with sodium hydroxide and water in the weight ratio $X_{k}=1$, where $X_{k}=m(\mathrm{C}) / m(\mathrm{NaOH})$.

The resulting mixture was observantly stirred over 1-2 h; thereaf- 
ter, it was dried in the thermostat to the constant weight at $90^{\circ} \mathrm{C}$. The dried material was placed in an oven and heated in argon atmosphere to $600^{\circ} \mathrm{C}$ (samples NC6), $700^{\circ} \mathrm{C}(\mathrm{NC} 7), 800^{\circ} \mathrm{C}(\mathrm{NC} 8)$, and $900^{\circ} \mathrm{C}(\mathrm{NC} 9)$ for $20 \mathrm{~min}$. After cooling, the resulting material was washed up in $5 \% \mathrm{HCl}$ aqueous solution to neutral $\mathrm{pH}$ and dried at $90^{\circ} \mathrm{C}$ up to constant weight.

The characteristics of porous structure (specific surface area and total pore volume) of NC were determined by analyzing the adsorption/desorption isotherms of nitrogen at its boiling point $(77 \mathrm{~K}) \mathrm{ob}$ tained using Quantachrome Autosorb Nova 2200e. Before the measurements, the samples were degassed in vacuum at $180^{\circ} \mathrm{C}$ for $18 \mathrm{~h}$. The specific surface area $\left(S_{\mathrm{BET}}, \mathrm{m}^{2} / \mathrm{g}\right)$ was determined by multipoint BET method in limited range of relative pressure $p / p_{0}=0.050-0.035$. The total pore volume $\left(V_{\text {total }}, \mathrm{cm}^{3} / \mathrm{g}\right)$ was calculated by the number of adsorbed nitrogen at $p / p_{0} \sim 1.0$. The volume of micropores $\left(V_{\text {micro }}, \mathrm{cm}^{3} / \mathrm{g}\right)$, the values of specific surface of micro- $\left(S_{\text {micro }}, \mathrm{m}^{2} / \mathrm{g}\right)$ and mesopores $\left(S_{\text {mezo }}, \mathrm{m}^{2} / \mathrm{g}\right)$ were found by using $t$-method [4].

The structural study was conducted by using scanning electron microscope JSM-6700 F with energy system JED-2300. For scanning electron microscopy, the thin layer of the sample was put into the epoxy resin piece. The sample size does not exceed $D=25 \mathrm{~mm}$ at a height of $10 \mathrm{~mm}$.

The electrodes of electrochemical capacitors (ECs) were prepared of a lamellar form from a mixture $\langle\mathrm{NC}\rangle:\langle\mathrm{CA}\rangle=\langle 75\rangle:\langle 25\rangle$, where CA is a conductive additive (KS-15 graphite (Lonza Group, Basel, Switzerland)). These symmetrical electrodes were infiltrated by the electrolyte separated by a separator and sealed in two-electrode cell of the ' 2525 ' size. $30 \% \mathrm{KOH}$ solution was used as the electrolyte. The investigation of electrochemical properties of ECs was conducted with galvanostatic and potentiodynamic cycling. The measurements were carried out on a set Autolab PGSTAT12 (ECO CHEMIE Company) equipped with GPES and FRA-2 software.

Galvanostatic measurements were conducted in voltage range of 0-1 $\mathrm{V}$; charge/discharge current changed within the range 10-150 mA.

The specific capacity was calculated by means of formula: $C=2 I t_{d} /\left[\left(U_{m}-\Delta U\right) m\right]$, where $I$-charge/discharge current, $t_{d}$ discharge time, $U_{m}$-maximum voltage, $\Delta U$-voltage drop at the closure of the discharge circuit, $m$-weight of NC. The $I R$ was determined by the potential jump after ten charge/discharge cycles: $\Delta U=I R$. The values of specific capacity according to potentiodynamic measurements were calculated as $C=2 I /(\mathrm{sm})$, where $I$-current in anodic or cathodic branches of voltammograms, $s$-scan rate, $m$-weight of NC.

\section{RESULTS AND DISCUSSION}

The necessary information for the calculation of the structural and morphological characteristics of the experimental samples of $\mathrm{NC}$ is 

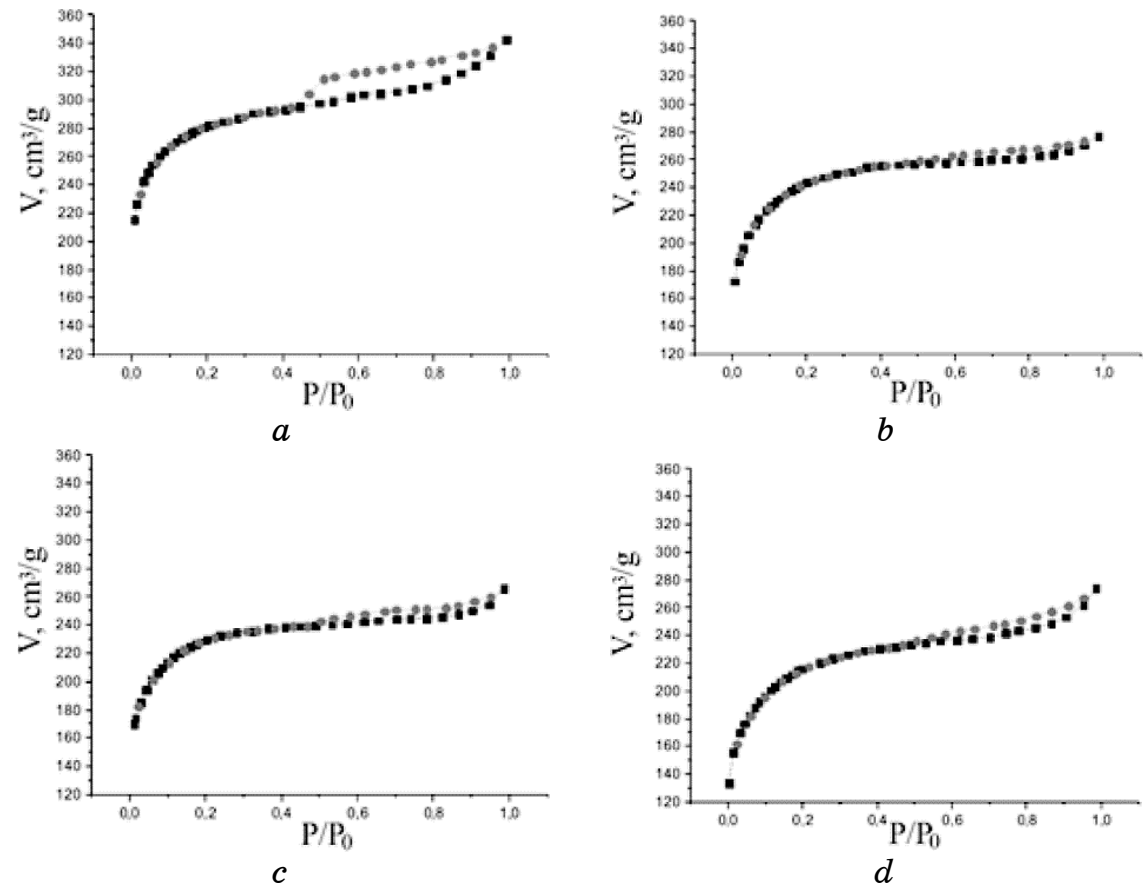

Fig. 1. Isotherms of nitrogen adsorption/desorption for carbon materials: a) NC6; $b$ ) NC7; c) NC8; d) NC9.

given by the experimental dependences of the change in the volume $V$ of adsorbed/desorbed nitrogen on the value of its relative pressure $p / p_{0}$ at constant temperature (Fig. 1). As seen from these curves, the amount of sorbed nitrogen gradually decreased with increasing of activation temperature.

Isotherms of adsorption/desorption of nitrogen for all carbon samples are similar and characteristic for polymolecular adsorption in micro- and mesoporous materials of organic origin. There is a H4-type hysteresis loop classified by IUPAC for all samples, which is associated with capillary condensation in the mesoporous [5]. Mesopores are the transport channels for the passage of adsorbate or electrolyte into micropores. Analyzing isotherms of adsorption/desorption, the values of the area and volume of micro- and mesoporous are determined (Table).

NCs obtained are characterized by a microporous structure with an average pore diameter of $2 \mathrm{~nm}$ and a specific surface area of 900-1000 $\mathrm{m}^{2} / \mathrm{g}$ (Table). There is a burning out of the carbon frame at increasing of activation temperature, which is accompanied by a decreasing in the number of micropores and their merging into mesopores. This is confirmed by an increase in the average pore diameter from 1.89 to $2.11 \mathrm{~nm}$ for temperatures of $700-900^{\circ} \mathrm{C}$. Comparing the results of specific sur- 
face area of NCs obtained at different activation temperatures, it is observed decrease of it with increasing temperature of chemical activation.

The pore size distribution of the investigated NCs (Fig. 2) was calculated using the density functional theory (DFT) in approximation of slit-shaped pores. This method used the quantum-mechanical calculations to describe the adsorption isotherms and pore-size distribution. The essence of the approach is to construct theoretical isotherms for different adsorbent-adsorbate pairs and compare them with experimentally obtained ones.

The largest number of micro- and mesoporous is observed at $600^{\circ} \mathrm{C}$ (sample NC6). The amount of micropores decreases, when the activa-

TABLE. Structural-adsorption parameters of NCs.

\begin{tabular}{|c|c|c|c|c|c|c|}
\hline Sample & $S_{\mathrm{BET}}, \mathrm{m}^{2} / \mathrm{g}$ & $S_{\text {micro }}, \mathrm{m}^{2} / \mathrm{g}$ & \begin{tabular}{l|}
$\mathrm{g} \mid V_{\text {micro }}, \mathrm{cm}^{3} / \mathrm{g}$ \\
\end{tabular} & \begin{tabular}{l|l}
$\mathrm{g}$ & $S_{\text {meso }}, \mathrm{m}^{2} / \mathrm{g}$
\end{tabular} & $V_{\text {total }}, \mathrm{cm}^{3} / \mathrm{g}$ & $d, \mathrm{~nm}$ \\
\hline NC6 & 1056 & 1040 & 0.48 & 45 & 0.53 & 2.01 \\
\hline NC7 & 906 & 898 & 0.39 & 20 & 0.43 & 1.89 \\
\hline NC8 & 859 & 854 & 0.37 & 23 & 0.41 & 1.92 \\
\hline NC9 & 802 & 766 & 0.39 & 34 & 0.42 & 2.11 \\
\hline
\end{tabular}
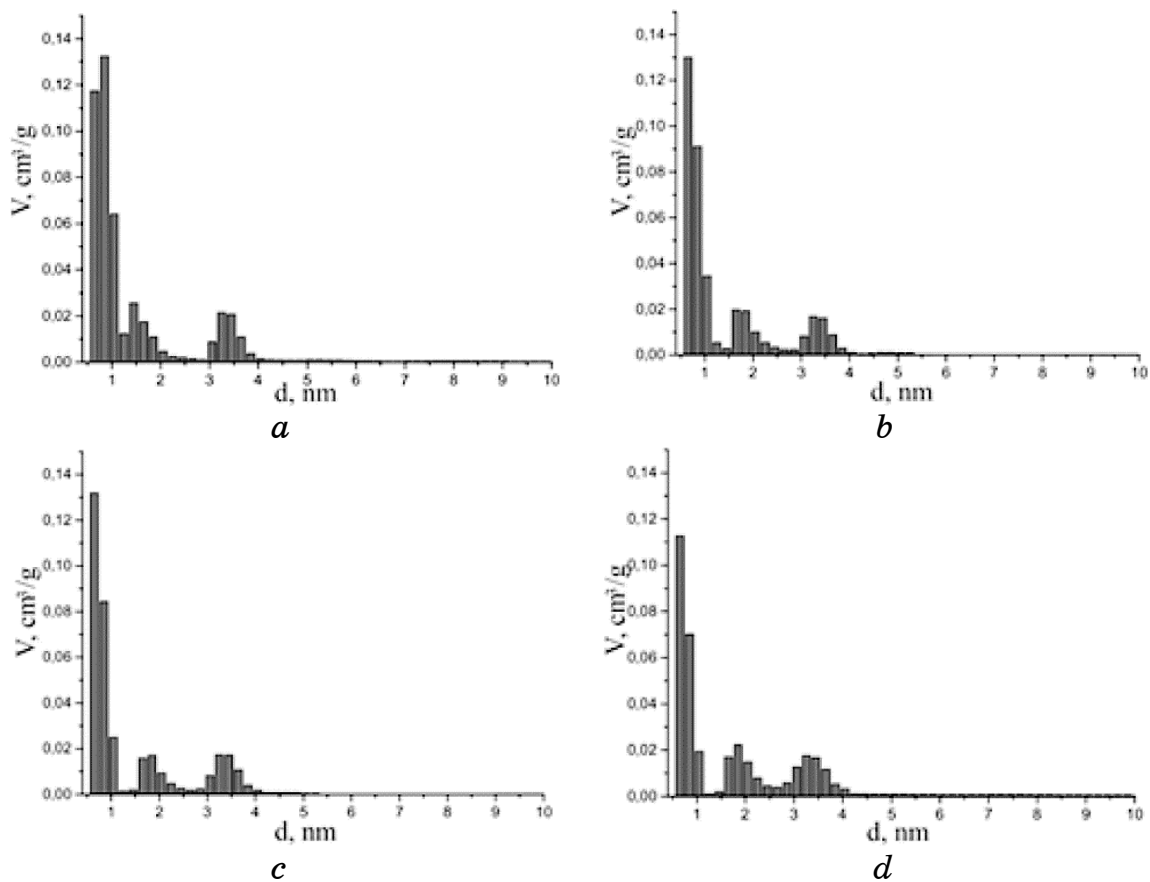

Fig. 2. Pore size distribution for carbon materials according to DFT-method: a) NC6; b) NC7; c) NC8; d) NC9. 

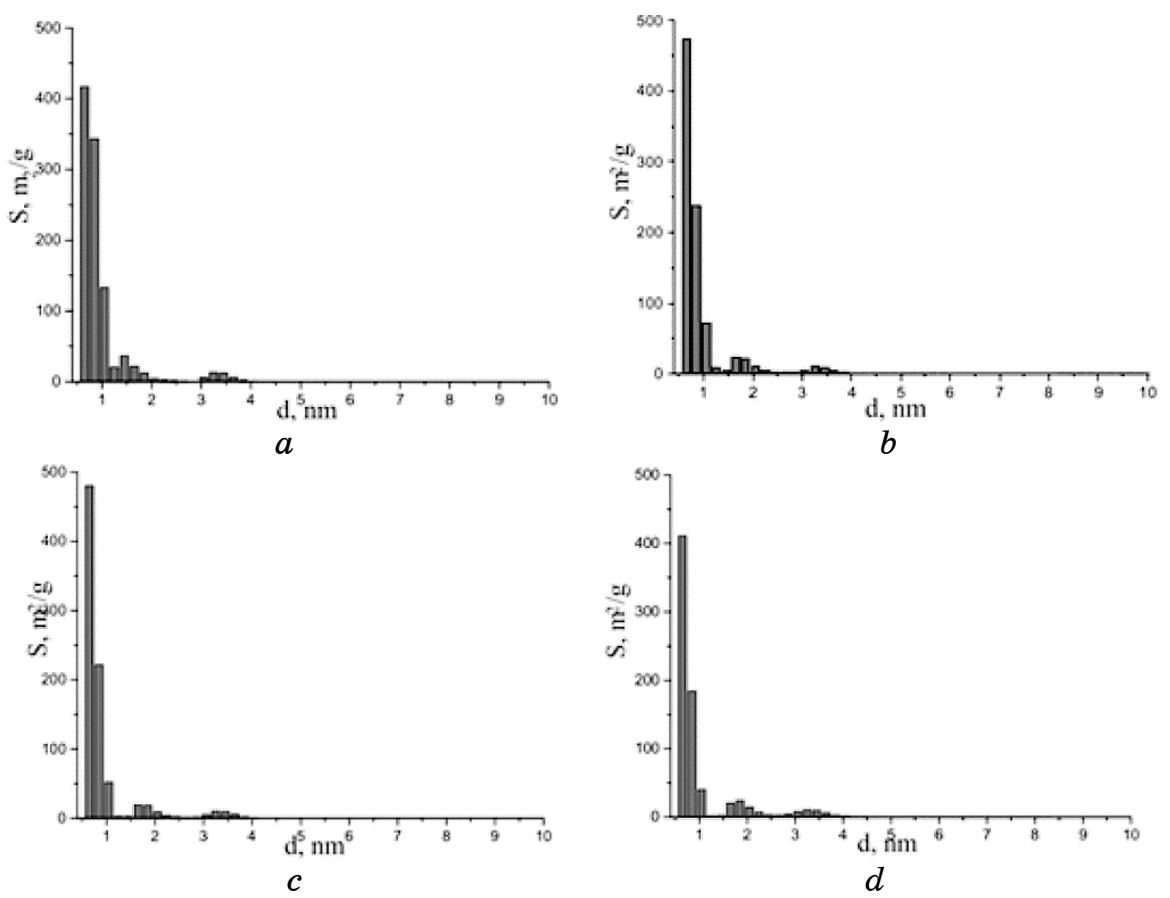

Fig. 3. Pore area distribution for carbon materials according to DFT-method: a) NC6; $b$ ) NC7; ) NC8; $d$ ) NC9.

tion temperature increases, as part of the burning lingocellulosic material increases. All materials contain mesopores of $2-4 \mathrm{~nm}$ in size (Fig. 3). Depending on the technological regimes, the nanoporous material has a different morphology. Maximum surface area $\left(1056 \mathrm{~m}^{2} / \mathrm{g}\right)$ is observed for the sample obtained at activation temperature of $600^{\circ} \mathrm{C}$ (Table). The porous structure and surface morphology will determine the physical and electrochemical properties of the resulting NCs.

The results of low-temperature porometry are in a good agreement with the data of electron-microscopy investigations (Fig. 4). The images clearly show the surface microcracks and the presence of round or oval transport pores of $0.4-4 \mu \mathrm{m}$ in size.

Throughout the surface, there are inclusions of white colour associated with ash residues and products of the interaction of sodium hydroxide with carbonaceous material. There are also needle-like and fibrous inclusions in the form of blurry rings in the structure of the material.

The pore size decreases to $50 \mathrm{~nm}$, when the activation temperature increases from 600 to $700^{\circ} \mathrm{C}$. Pores become irregular, and microcracks are observed in the range of activation temperature of $700-800^{\circ} \mathrm{C}$ (Fig. $4, b, c)$ The number of pores is reduced significantly as well as the amount of ash residues significantly increases at $900^{\circ} \mathrm{C}$. 

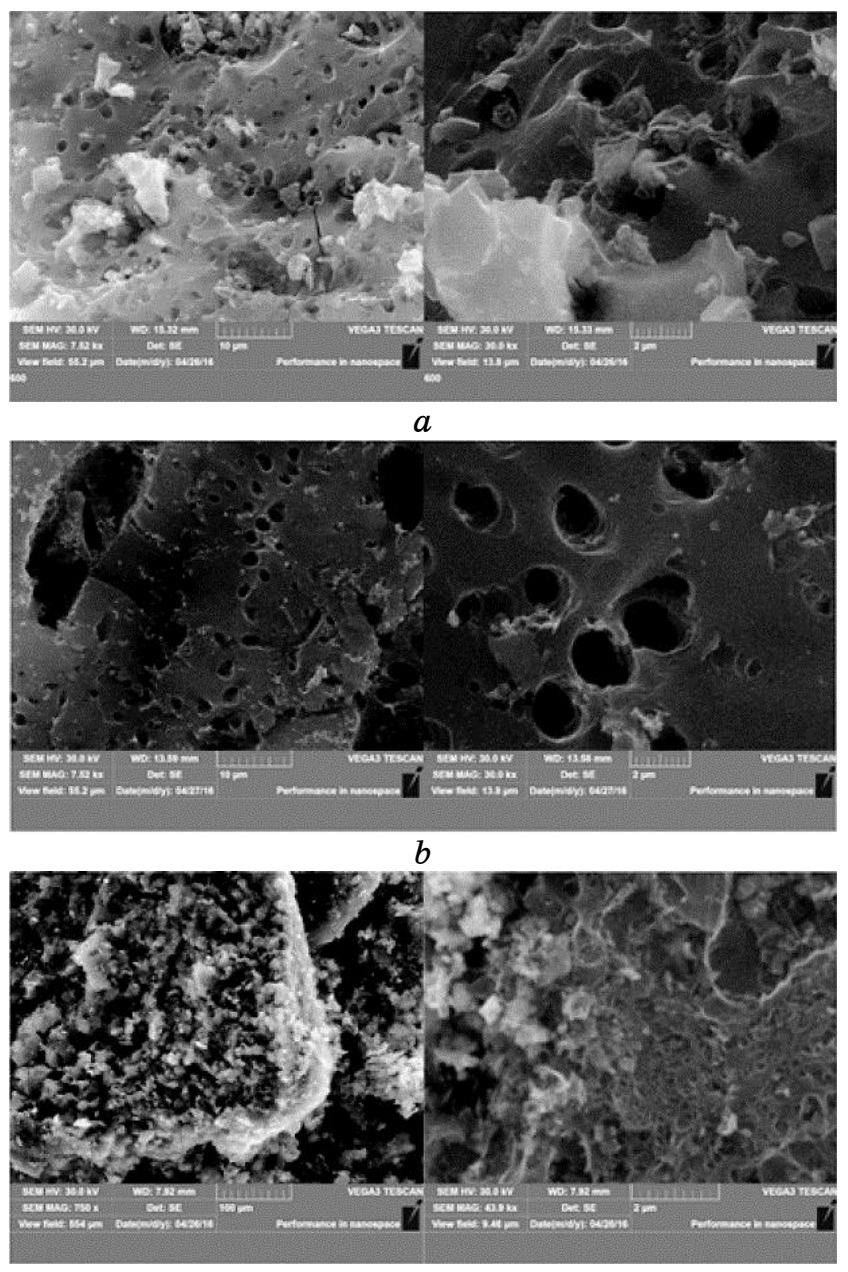

$c$

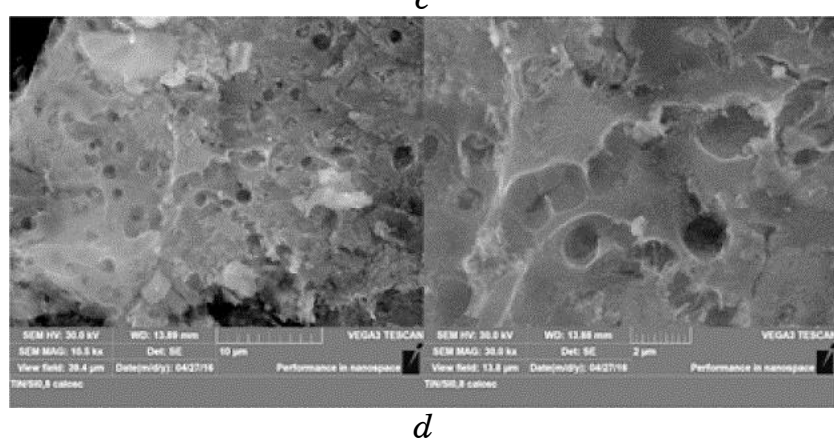

Fig. 4. SEM images of carbon material surface: $a$ ) NC6; b) NC7; $c$ ) NC8; $d$ ) NC9.

To study the effect of the activation temperature of the raw material 
on the specific energy-capacity characteristics of NCs, the dependence of the specific capacity of NCs on the discharge current was calculated according to the results of galvanostatic studies. It is set that activation at $600,700,800$, and $900^{\circ} \mathrm{C}$ allows obtaining a carbon material with a specific capacity of $140,91,95$, and $62 \mathrm{~F} / \mathrm{g}$, respectively, at discharge current of $50 \mathrm{~mA}$.

It was found that the specific capacity for the sample NC6 is practically unchanged in the whole range of discharge currents (10-200 $\mathrm{mA}$ ). Probably, this regularity is associated with a presence of large number of mesopores in material, which are transport channels that provide the availability of electrolyte ions to micropores at high discharge currents. All curves are characterized by a monotonous recession as the discharge current increases. The reason for this dependence is that micropores with a narrow radius of $<2 \mathrm{~nm}$ dominate in these materials, so there is a growth in the internal resistance of the capacitor with increasing of discharge current. A characteristic feature of
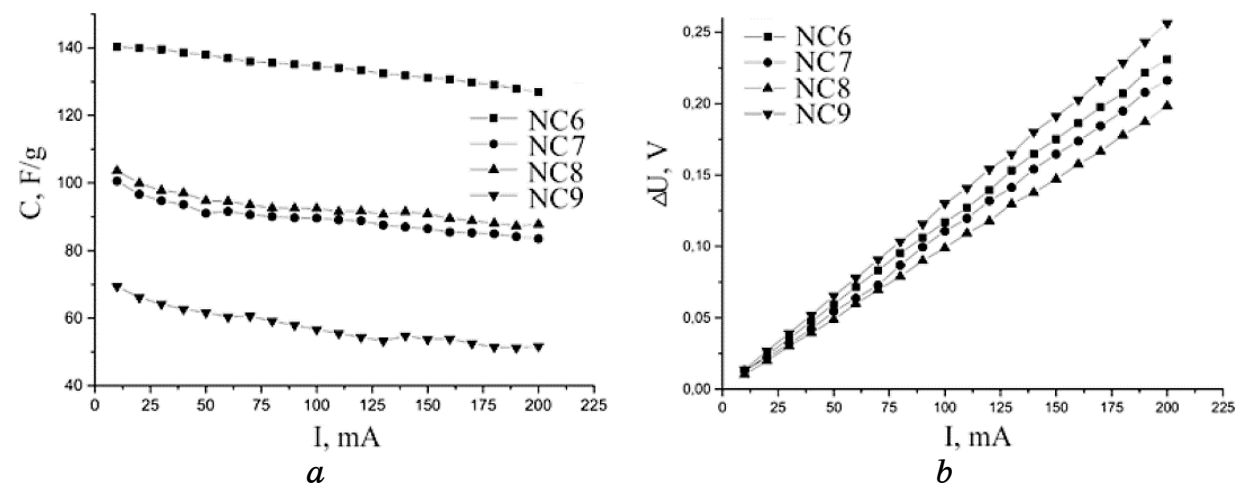

Fig. 5. The dependences of specific capacity of NCs $(a)$ and voltage drop $(b)$ on discharge current.

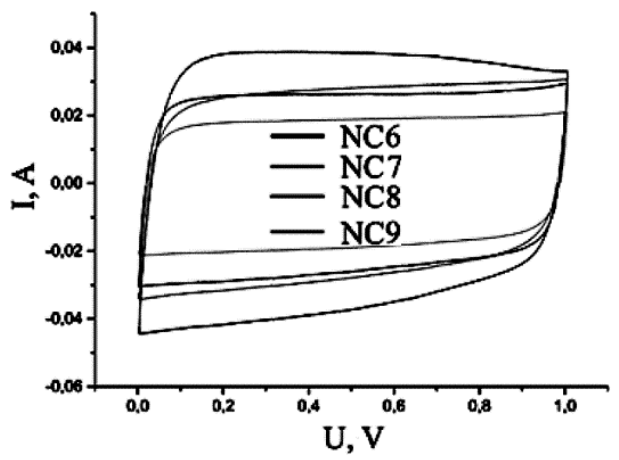

Fig. 6. Cyclic voltamperograms of ECs at scan rate of $2.5 \mathrm{mV} / \mathrm{s}$. 
the investigated materials is that the capacity decreasing does not exceed $25 \%$ at discharge currents of $10-100 \mathrm{~mA}$ that indicates the prospect of these materials using as electrodes of supercapacitors [6].

The sharp voltage drop $\Delta U$ at constant charge/discharge current indicates the presence of an internal resistance of the porous carbon material/electrolyte electrochemical system. If the voltage drop exceeds $20 \%$ of the maximum, the discharge current must be lowered by two, five, or ten times. Figure $5, b$ shows the dependence of the voltage drop of ECs from the applied discharge current.

Cyclic voltamperometry in the field of electrochemistry is widely used to estimate the energy characteristics of storage devices and transformation of electrical energy such as electrochemical capacitors, batteries, and power supplies. This method allows investigate the dependence of current on the applied potential, which periodically changes over a certain time [7]. Figure 6 shows cyclic voltamperograms of ECs at scan rate of $2.5 \mathrm{mV} / \mathrm{s}$ in the range $0-1 \mathrm{~V}$.

The general view of voltamperograms on NC base is typical for ECs
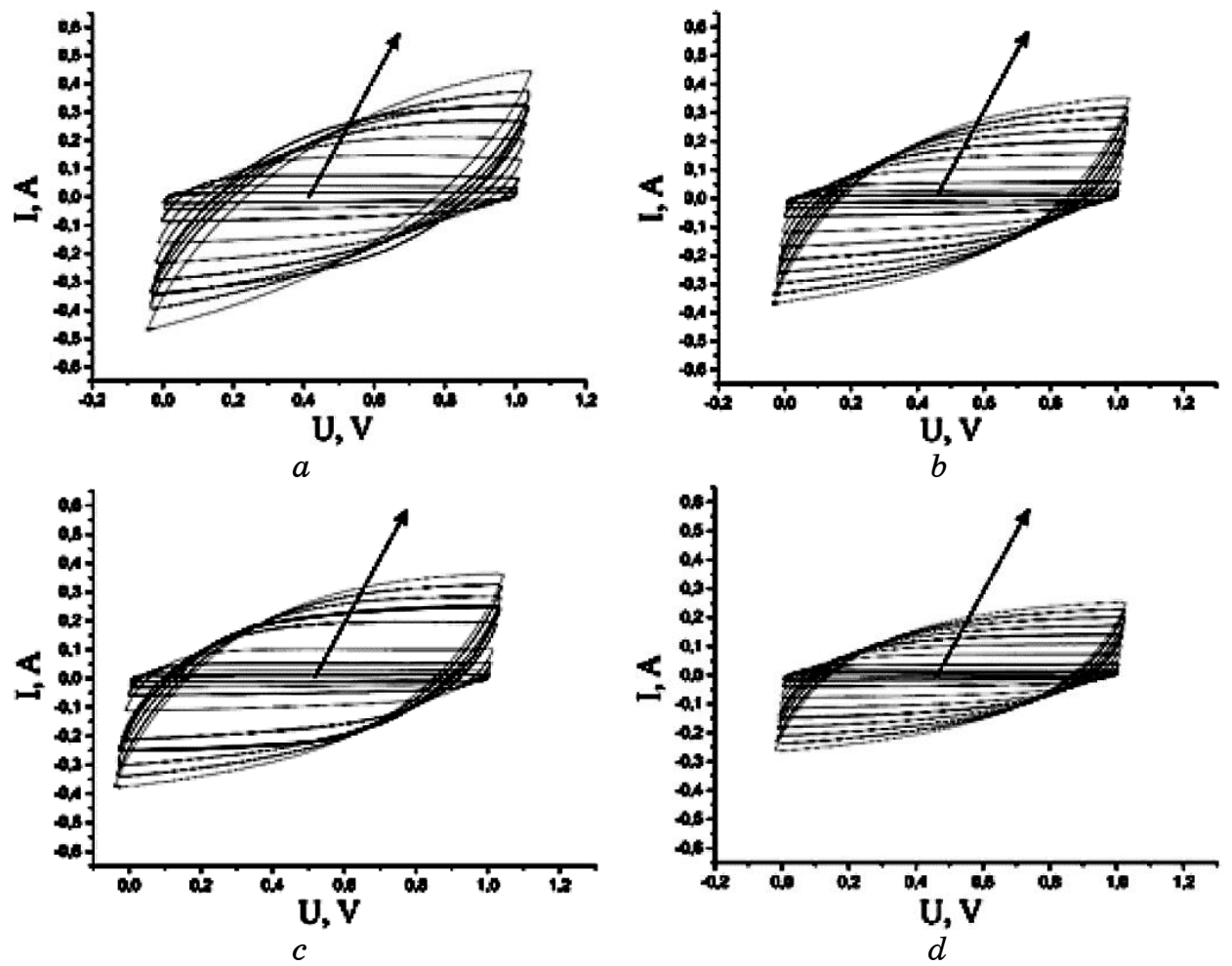

Fig. 7. Cyclic voltamperograms of ECs on NC base: $a$ ) NC6; $b$ ) NC7; $c$ ) NC8; $d$ ) NC9. Scan rate is of $1,2.5,5,10,15,20,25,30,35,40 \mathrm{mV} / \mathrm{s}$. 
operating on the principle of DEL charge/discharge. The dependences have a symmetrical form at a scan rate of $2.5 \mathrm{mV} / \mathrm{s}$, indicating a quasireversibility of charge/discharge of DEL. A slight peak is observed on voltamperograms at potentials $0.85-1 \mathrm{~V}$ for all samples. If we take into account that the materials' capacity is provided mainly by negative electrolyte ions (OH-groups) in this area, one can conclude that a process of these groups' introduction into the pores of the electrode material [8] is possible.

Figure 7 shows cyclic voltamperograms of ECs. All samples exhibit ideal polarization at low scan rate $(s=1-10 \mathrm{mV} / \mathrm{s})$. There is a slight distortion of the voltamperograms and their deviation from the rectangular shape, when the scan speed increases. This may be due to an increase in the internal resistance of EC and the initial stage of the 'starvation' electrolyte effect, when the charged electrolyte ions are removed at their adsorption at the DEL boundaries.

\section{CONCLUSIONS}

It is set that the most efficient electrode material for EC is carbon material obtained by carbonization of plant material at $600^{\circ} \mathrm{C}$ and chemically activated by $\mathrm{NaOH}$, when $\mathrm{C} / \mathrm{NaOH}$ ratio is $1: 1$. It is shown that $\mathrm{NC}$ is formed with pore sizes of $0.8-10 \mathrm{~nm}$ at carbonization temperature of $600-900^{\circ} \mathrm{C}$ and chemical activation of raw materials by $\mathrm{NaOH}$ with the ratio $\mathrm{C} / \mathrm{NaOH}=1: 1$.

\section{REFERENCES}

1. I. F. Myronyuk, V. I. Mandzyuk, V. M. Sachko, and V. M. Gun'ko, Nanoscale Research Letters, 11: No. 508: 1 (2016).

2. R. Ya. Shvets, I. I. Grygorchak, A. K. Borysyuk, S. G. Shvachko, A. I. Kondyr, V. I. Baluk, A. S. Kurepa, and B. I. Rachiy, Physics of the Solid State, 56, No. 10: 2021 (2014).

3. I. F. Myronyuk, V. I. Mandzyuk, V. M. Sachko, R. P. Lisovsky, and B. I. Rachiy, Journal of Nano- and Electronic Physics, 8, No. 3: 03017-1 (2013).

4. S. Gregg and K. Sing, Adsorption, Surface Area and Porosity (London: Academic: 1982).

5. A. P. Karnaukhov, Adsorption. Texture of Dispersed and Porous Materials (Novosibirsk: Nauka: 1999).

6. P. Kurzweil, Proceedings of the 12-th International Seminar on Double Layer Capacitors and Similar Energy Storage Devices (Deerfield Beach, Florida, USA: 2004), vol. 14, p. 18.

7. H. Wang, H. Wang, and L. Pilon, Electrochimica Acta, 64: 130 (2012).

8. B. E. Conway, Electrochemical Supercapacitors. Scientific Fundamentals and Technological Applications (New York: Kluwer Academic Plenum Publishers: 1999). 